\title{
Synthesis of the Proposed Structure of Damaurone D and Evaluation of Its Anti-inflammatory Activity
}

\author{
Young Taek Han, ${ }^{* a}$ Zheng Wang, ${ }^{b}$ and Eun Ju Bae ${ }^{b}$ \\ ${ }^{a}$ College of Pharmacy, Dankook University; Cheonan 330-141, Korea: and ${ }^{b}$ College of Pharmacy, Woosuk \\ University; Wanju 565-701, Korea. \\ Received July 2, 2015; accepted August 11, 2015; advance publication released online August 20, 2015
}

\begin{abstract}
Concise and efficient synthesis of the proposed structure of damaurone $D$ is accomplished in five steps without protection-deprotection operations. The key feature of our synthesis includes a versatile aldol reaction of the benzofuranone, provided by selective $\alpha$-halogenation and intramolecular $O$-alkylation. However, the H- and C-NMR spectral data of the synthesized damaurone D did not agree with previous reports. The structure of the synthesized damaurone D was confirmed using combined two dimensional (2D)-NMR analysis, including heteronuclear single quantum coherence (HSQC), heteronuclear multiple bond connectivity (HMBC), and nuclear Overhauser effect spectroscopy (NOESY). The synthesized damaurone D was found to exhibit potent anti-inflammatory activity in murine macrophage RAW264.7 cells, which was demonstrated by the findings that damaurone $D$ treatment in cells resulted in the inhibition of lipopolysaccharide (LPS)stimulated inducible nitric oxide synthase (iNOS) and cyclooxygenase-2 (COX-2) expression and nitrite production.
\end{abstract}

Key words damaurone D; synthesis; anti-inflammatory activity; aurone; selective $\alpha$-bromination

Aurones [2-benzylidenebenzofuran-3(2H)-ones], flavonoid constituents of the yellow pigmentation in flowers and fruits, ${ }^{1)}$ exhibit a strong and broad variety of biological efficacies such as fungicidal, antiviral, anti-tyrosinase and antioxidant activities. ${ }^{2}$ In this regard, these aurones and their derivatives have been considered as attractive targets in terms of both synthetic $^{3)}$ and medicinal chemistry. ${ }^{4,5)}$ Recently, damaurone D (1), an isoprenylated aurone, was isolated by Lei et al. from Rosa damascena, a plant that belongs to genus Rosa. ${ }^{6}$ The genus Rosa including Rosa damascena has not only been used for gardening and cosmetics, but also as a traditional medication to treat depression, inflammation, and infectious diseases." Based on these interesting biological activities, numerous research including identification of novel drug candidates, as well as its applications, have been performed using the extracts and single chemical constituents of Rosa damascena. ${ }^{8-10)}$ Considering not only the therapeutic properties of aurones and Rosa damascena as mentioned above, but also the existence of a chromane moiety, one of the privileged structures in medicinal chemistry, ${ }^{11)}$ damaurone D is strongly expected to have therapeutically useful biological activities. Furthermore, it is believed that its unique dihydropyrano- aurone moiety may be a useful novel scaffold for further medicinal chemistry research such as the construction of natural product-like libraries.

To establish a synthetic procedure for damaurone D (1), that could be used for further derivatization, we planned a versatile aldol condensation between benzofuranone 2 and 4-hydroxybenzaldehyde, a general synthetic approach for $Z$-aurone derivatives. $^{12,13)}$ Benzofuranone 2 was expected to be obtained by $\alpha$-halogenation, followed by intramolecular $O$-alkylation of 2-hydroxyacetophenone 3 , which could be prepared from commercially available 2,4-dihydroxyacetophenone 4 by regioselective chromene annulation and subsequent hydrogenation. Alternatively, benzofuranone $\mathbf{2}$ was expected to be prepared by chromene annulation followed by hydrogenation of commercially available hydroxycoumaranone 5 (Fig. 1).

Natural compounds that have an enone structure between two aromatic rings such as chalcones and aurones are generally considered as Michael acceptors which can covalently bind biomolecules, and exhibit interesting pharmacological activities. ${ }^{14)}$ For instance, butein, a polyphenolic chalcone, and sulfuretin, one of the aurones isolated from Rhus verniciflua, have been shown to possess an anti-inflammatory function in
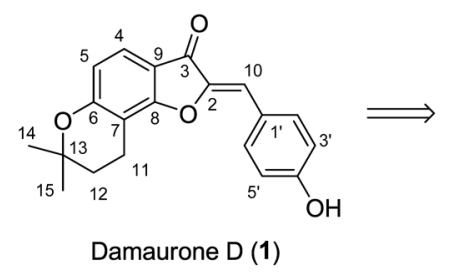<smiles>C1=CCCC1</smiles><smiles>CC1(C)CCc2c(ccc(C(=O)O)c2O)O1</smiles><smiles>O=C1COc2cc(O)ccc21</smiles>

5

Fig. 1. Proposed Structure of Damaurone D (1) and Retrosynthetic Analysis 
vitro and in vivo. ${ }^{15-17)}$ Given that damaurone D (1) has similar enone structure to the natural anti-inflammatory compounds, herein, we examine whether damaurone D (1) exerts antiinflammatory action in macrophages.

\section{Results and Discussion}

As shown in Chart 1, our synthesis commenced with preparation of benzofuranone 2 , a precursor to the versatile aldol reaction. Pyridine-catalyzed condensation ${ }^{18)}$ under microwave irradiation between 2,4-dihydroxyacetophenone 4 and 3-methyl-2-butenal regioselectively gave the known chromene $\mathbf{6},{ }^{19}$ ) which was subjected to hydrogenation using palladium on carbon as a catalyst to afford chromane 3 . This two-step procedure to obtain the chromane structure was more regioselective than previously described one-step reaction using isoprene. ${ }^{20)}$ In addition, microwave irradiation enhanced the reaction rate with a slightly improved chemical yield than the reflux conditions described in a previous study. ${ }^{19)}$ However, interestingly, chromene annulations of hydroxycoumaranone $\mathbf{5}$ to synthesize chromene $\mathbf{8}$ under microwave irradiation and reflux conditions afforded only a mixture of aldol adducts. This may be attributed to the difference in nucleophilicity of the carbonyl $\alpha$-carbon between the 3 -coumaranone and acetophenone structures. To prepare the key intermediate benzofuranone 2 from 2-hydroxyacetophenone $\mathbf{3}$, as shown in Table 1 , we attempted $\alpha$-bromination reactions using several brominating reagents such as copper(II) bromide, ${ }^{21)} \mathrm{N}$-bromosuccinimide (NBS), ${ }^{22)}$ and bromine. ${ }^{23)}$ However, we could obtain only inseparable regioisomeric mixtures of the undesired aromatic bromination product 9 in all our experiments carried out in direct $\alpha$-bromination conditions (entries 1-4) that are generally used for the preparation of a benzofuran-3-one structure from 2-hydroxyacetophenones. It was supposed that the nucleophilicity of the aromatic ring of 2-hydroxyacetophenone 3 was increased enough by electron-donating substituents to overcome the reactivity of the carbonyl $\alpha$-carbon. It was also anticipated that a substrate possessing more nucleophilic carbonyl $\alpha$-carbon than aromatic rings would undergo an $\alpha$-bromination reaction selectively. Based on this idea, we performed a two-step $\alpha$-bromination via trimethylsilyl (TMS) enol ether 10, equivalent to a highly nucleophilic enolate, ${ }^{24)}$ and observed the $\alpha$-bromination product 7 as expected (entry 5). Benzofuranone 2 was readily obtained in moderate yield from crude bromoacetophenone 7, with a trace amount of 9 $(<3 \%)$, by an intramolecular $O$-alkylation reaction. Finally, we successfully synthesized the proposed structure of damaurone D $\mathbf{1}$ by aldol condensation between benzofuranone 2 and 4-hydroxybenzaldehyde using piperazine as a catalyst. The structure of synthesized $\mathbf{1}$ was assigned and confirmed by two dimensional (2D)-NMR analysis including heteronuclear multiple quantum coherence (HMQC), heteronuclear multiple bond connectivity (HMBC), and nuclear Overhauser effect spectroscopy (NOESY). Selected HMBC correlations and our assignments are shown in Fig. 2A and Table 2, respectively. The geometry of the double bond was confirmed as $Z$ con-

Table 1. Bromination Reactions of 2-Hydroxyacetophenone 3

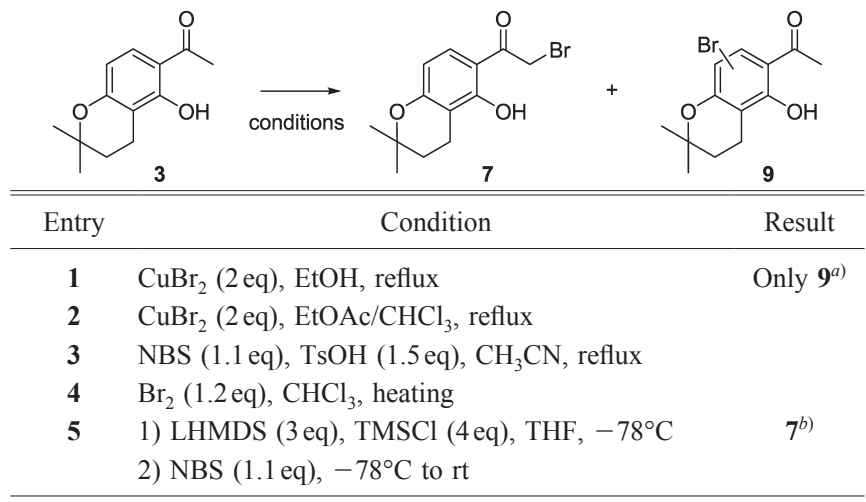

a) Yields were not determined. $b)$ Trace amount of $9(<3 \%)$ was isolated afte intramolecular $O$-alkylation reaction.<smiles>CC(=O)c1ccc(O)cc1O</smiles><smiles>CC1(C)CCc2c(ccc(C(=O)CBr)c2O)O1</smiles><smiles>Cc1c(C(C)C)ccc2c1CCC(C)(C)O2</smiles><smiles>C=C(O[Na])c1ccc2c(c1OC)CCC(C)(C)O2</smiles>
10

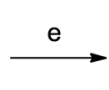<smiles>CC1(C)CCc2c(ccc3c2O/C(=C\c2ccc(O)cc2)C3=O)O1</smiles><smiles>CC(C)(C)COc1cc(O)ccc1C(=O)CO</smiles><smiles>CC1(C)C=Cc2c(ccc3c2OCC3=O)O1</smiles>

Reagents and conditions: (a) 3-Methyl-2-butenal, pyridine, microwave irradiation, $140^{\circ} \mathrm{C}, 2 \mathrm{~h}, 71 \%$; (b) $10 \% \mathrm{Pd} / \mathrm{C}, \mathrm{H}_{2}$, EtOAc, rt, $99 \%$; (c) $1 \mathrm{M} \mathrm{LHMDS}$ in THF, TMSCl, THF, $-78^{\circ} \mathrm{C}, 4 \mathrm{~h}$; then $\mathrm{N}$-bromosuccinimide, $-78^{\circ} \mathrm{C} \rightarrow \mathrm{rt}, 1 \mathrm{~h}$; (d) $1 \mathrm{M} \mathrm{NaOH}, \mathrm{H}_{2} \mathrm{O}, \mathrm{rt}, 1 \mathrm{~h}, 64 \%$ in 2 steps; (e) 4-Hydroxybenzaldehyde, piperazine, EtOH, reflux, overnight, $94 \%$. 

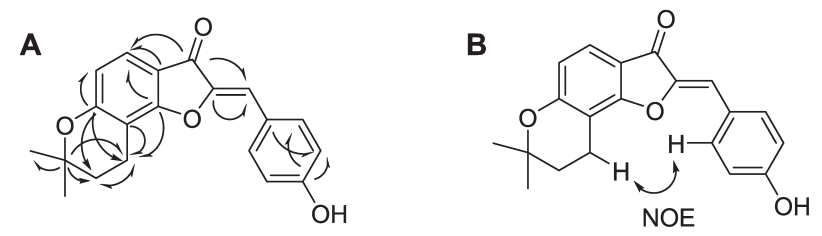

Fig. 2. Selected HMBC Correlation (A) and NOE Correlation (B) for Synthesized Damaurone D

Table 2. ${ }^{1} \mathrm{H}$ - and ${ }^{13} \mathrm{C}-\mathrm{NMR}$ Assignments of Damaurone D (1)

\begin{tabular}{cccccc}
\hline \hline \multirow{2}{*}{ Position $^{a)}$} & \multicolumn{2}{c}{ Reported } & & \multicolumn{2}{c}{ Synthesized $^{b)}$} \\
\cline { 2 - 3 } \cline { 5 - 6 } & ${ }^{1}$ H-NMR & ${ }^{13}$ C-NMR & & ${ }^{1}$ H-NMR & ${ }^{13}$ C-NMR \\
\hline 2 & - & 146.1 & & - & 147.1 \\
3 & - & 181.3 & & 182.7 \\
4 & $7.39(\mathrm{~d})$ & 121.0 & & $7.66(\mathrm{~d})$ & 123.0 \\
5 & $6.66(\mathrm{~d})$ & 113.0 & & $6.73(\mathrm{~d})$ & 114.3 \\
6 & - & 164.0 & & - & 161.8 \\
7 & - & 115.4 & & - & 106.2 \\
8 & - & 160.6 & & - & 165.9 \\
9 & - & 113.9 & & 114.2 \\
10 & $6.62(\mathrm{~s})$ & 112.2 & & $7.17(\mathrm{~s})$ & 112.3 \\
11 & $2.58(\mathrm{dd})$ & 21.2 & & $2.67(\mathrm{t})$ & 16.0 \\
12 & $1.72(\mathrm{dd})$ & 33.1 & & $1.70(\mathrm{t})$ & 31.3 \\
13 & - & 73.9 & & - & 76.6 \\
14 & $1.52(\mathrm{~s})$ & 26.3 & & $1.27(\mathrm{~s})$ & 26.6 \\
15 & $1.52(\mathrm{~s})$ & 26.3 & & $1.27(\mathrm{~s})$ & 26.6 \\
$1^{\prime}$ & - & 126.3 & & - & 124.4 \\
$2^{\prime}, 6^{\prime}$ & $7.82(\mathrm{~d})$ & 131.1 & & $8.07(\mathrm{~d})$ & 134.1 \\
$3^{\prime}, 5^{\prime}$ & $6.89(\mathrm{~d})$ & 116.3 & & $7.33(\mathrm{~d})$ & 117.1 \\
$4^{\prime}$ & - & 158.2 & & - & 161.0 \\
$\mathrm{HO}^{\prime} \mathrm{C}\left(4^{\prime}\right)$ & $11.20(\mathrm{~s})$ & - & & $12.46(\mathrm{~s})$ & - \\
\hline
\end{tabular}

a) C-Atom numbering as indicated in Fig. 1. b) Pyridine- $d_{5}$ was used as the solvent.

figuration by the NOE correlation between benzylic protons $(\mathrm{H}-11)$ and aromatic protons $\left(\mathrm{H}-2^{\prime}, 6^{\prime}\right)$ as shown in Fig. 2B. In addition, the $Z$ configuration of the double bond in aurones also can be assigned by chemical shift of C-10 (112.3 ppm) in a range of $105.9-112.8 \mathrm{ppm}$. On the other hand, C-10 carbon signal of the alternative $E$ configuration would be observed between 119.9 and $121.5 \mathrm{ppm} .{ }^{6,25)}$ However, ${ }^{1} \mathrm{H}$ - and ${ }^{13} \mathrm{C}-\mathrm{NMR}$ data of 1 slightly differ from the reported data in spite of the same measurement conditions (pyridine- $d_{5}$ as the solvent and $500 \mathrm{MHz}$ as measurement frequency). The proton signal of $\mathrm{H}-10$ (numbering as indicated in Fig. 1) was reported in the previous study as $6.62 \mathrm{ppm}(\mathrm{s}, 1 \mathrm{H})$, the most up-field shifted peak among the aromatic and olefinic proton peaks. However, in our study, the singlet proton peak of H-10 was observed at $7.17 \mathrm{ppm}$, very close to the proton peaks of pyridine, between the peaks of H-3', H-5' (7.33 ppm) and H-5 (6.73 ppm). When we changed the NMR solvent to $\mathrm{CD}_{3} \mathrm{OD}$, the singlet proton peak of H-10 (6.78 ppm) was also observed between the peaks of H-3', H-5' (6.88 ppm) and $\mathrm{H}-5$ (6.62 ppm). In addition, the C-11 carbon signal in our study $(16.0 \mathrm{ppm})$ showed a difference of more than $5 \mathrm{ppm}$ in comparison with that previously reported (21.2 ppm). Considering ${ }^{13} \mathrm{C}-\mathrm{NMR}$ signals of the corresponding carbons of synthetic intermediates such as chromanes $\mathbf{3}(16.2 \mathrm{ppm})$ and $\mathbf{2}(15.7 \mathrm{ppm})$, prepared from the known chromene $\mathbf{6}$, our assignment of the C-11 carbon seems to be more reasonable.
With the proposed structure of damaurone D (1) in hand, we examined its anti-inflammatory activity as a preliminary evaluation of its biological activities. Firstly, we determined the non-cytotoxic concentration range of $\mathbf{1}$ in RAW264.7 macrophage cells. As shown in Fig. 3A, the cell viability in RAW264.7 cells was not affected by 1 up to a concentration of $20 \mu \mathrm{M}$, thus, subsequent experiments were conducted at 10 and $20 \mu \mathrm{M}$ of 1 . We next examined the concentration-dependent effect on inducible nitric oxide synthase (iNOS) and cyclooxygenase-2 (COX-2) induction. Lipopolysaccharide (LPS) treatment for $24 \mathrm{~h}$ in RAW264.7 cells led to the marked induction of iNOS and COX-2, however, pretreatment with $\mathbf{1}$ at 10 and $20 \mu \mathrm{M}$ for $1 \mathrm{~h}$ significantly suppressed the expression of iNOS and COX-2, being equipotent to butein (Fig. 3B). Consistently, nitrite production in response to LPS treatment was significantly inhibited by pretreatment with 1 (Fig. 3C) indicating synthesized damaurone D (1) has potent anti-inflammatory efficacy.

\section{Conclusion}

In summary, concise and efficient synthesis of the proposed structure of damaurone D was accomplished in five steps without protection-deprotection operations. The key intermediate benzofuranone 2 , which can be used as a versatile intermediate for the synthesis of various dihydropyrano-aurones, was provided by selective $\alpha$-halogenation, and subsequent intramolecular $O$-alkylation. The spectral data of the synthesized damaurone D did not agree with that in previous report. Structure of synthesized damaurone D was confirmed by combined 2D-NMR analysis, including HSQC and HMBC. Synthesized damaurone D was found to exhibit potent antiinflammatory activity in murine macrophage RAW264.7 cells. On the basis of these results, further biological evaluation of $\mathbf{1}$ and its derivatives as potential anti-inflammatory agents is currently making good progress, and results will be reported in due course.

\section{Experimental}

General Unless noted otherwise, all starting materials and reagents were obtained commercially and were used without further purification. Tetrahydrofuran was distilled from sodium benzophenone ketyl. All solvents used for routine product isolation and chromatography were of reagent grade and glass distilled. Reaction flasks were dried at $100^{\circ} \mathrm{C}$ before use, and air and moisture sensitive reactions were performed under argon. Flash column chromatography was performed using silica gel 60 (230-400 mesh, Merck) with the indicated solvents. Thin-layer chromatography was performed using $0.25 \mathrm{~mm}$ silica gel plates (Merck). Mass spectra were obtained using a VG Trio-2 GC-MS instrument, and high resolution mass spectra were obtained using a JEOL JMS-AX 505WA unit. Infrared spectra were recorded on a Fourier transform (FT)-IR spectrometer. ${ }^{1} \mathrm{H}$ and ${ }^{13} \mathrm{C}$ spectra were recorded on a JEOL JNM-LA 300, Bruker Analytik ADVANCE digital 400 or ADVANCE digital 500 in deuteriochloroform $\left(\mathrm{CDCl}_{3}\right)$, deuteriomethanol $\left(\mathrm{CD}_{3} \mathrm{OD}\right)$ or deuterated pyridine (pyridine$d_{5}$ ). Chemical shifts are expressed in parts per million (ppm, $\delta$ ) downfield from tetramethylsilane and are referenced to the deuterated solvents. ${ }^{1} \mathrm{H}-\mathrm{NMR}$ data are reported in the order; chemical shift, multiplicity (s, singlet; brs, broad singlet; $d$, doublet; t, triplet; q, quartet; m, multiplet, and/or multiple res- 
A

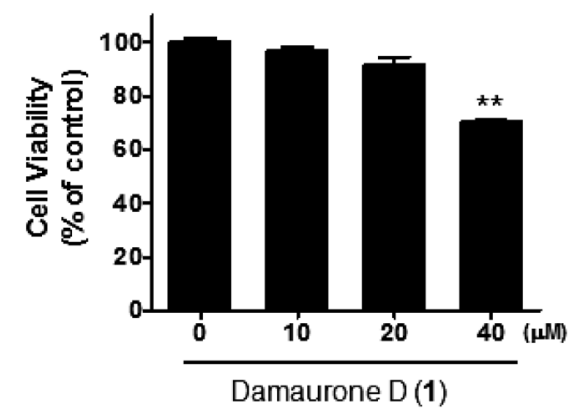

C

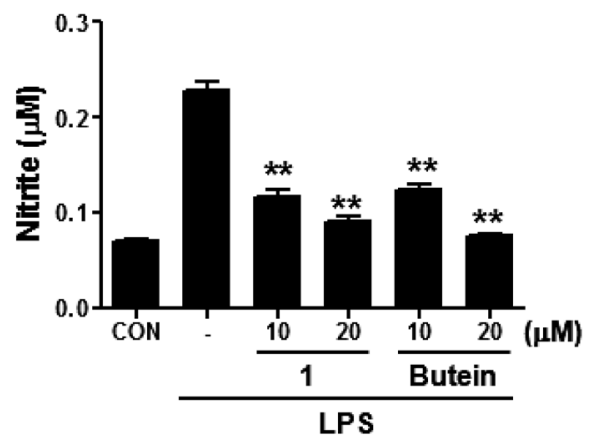

B
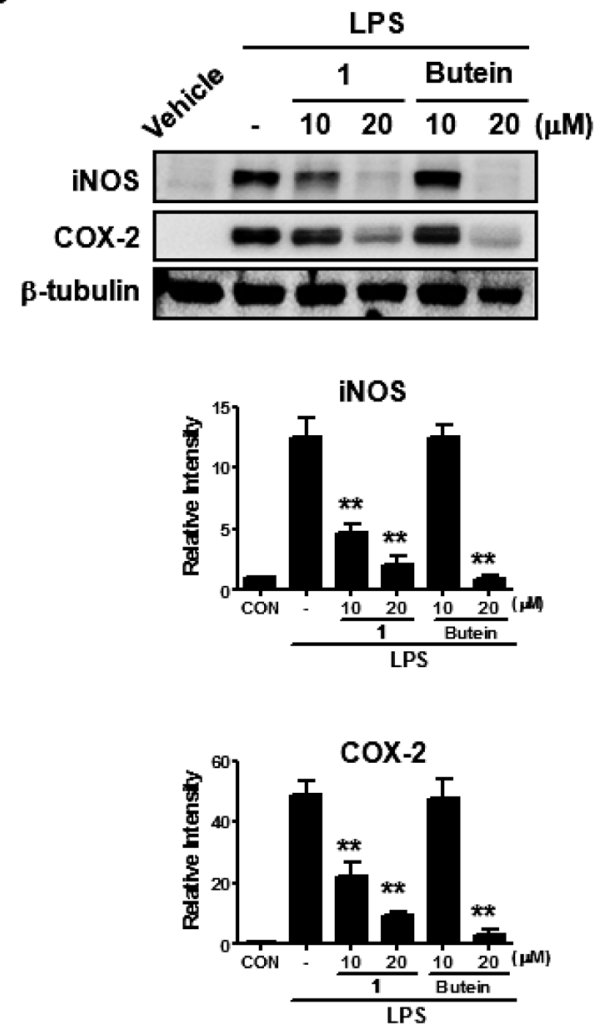

Fig. 3. (A) Effect of Synthesized Damaurone D (1) on Cell Viability of RAW264.7 Macrophages; (B) 1 Inhibited iNOS and COX-2 Protein Expression in RAW264.7 Cells; (C) Nitrite Production Was Measured in the Cells from (B)

(A) RAW264.7 cells were treated with 1 at 10, 20 and $40 \mu \mathrm{M}$ for $24 \mathrm{~h}$ in the presence of serum, and subsequently subjected to an MTT assay. The results are expressed as the mean \pm S.E.M. (B) Cells were treated with LPS $(10 \mathrm{ng} / \mathrm{mL})$ in the absence or presence of 1 or butein at 10 and $20 \mu \mathrm{m}$ for $24 \mathrm{~h}$. $\beta$-Tubulin was used as a loading control. The experiments were repeated at least three times, and the relative levels of iNOS and COX-2 expression analyzed by densitometry are shown in the lower bar graph. $* * p<0.01$ vs. LPS-treated group.

onance, numbers of protons, and coupling constants in hertz (Hz). HMQC and HMBC were recorded on Bruker Avance III $700 \mathrm{MHz}$ in deuterated pyridine.

1-(5-Hydroxy-2,2-dimethyl-2H-chromen-6-yl)ethanone (6) To a solution of 2,4-dihydroxyacetophenone $4(2.00 \mathrm{~g}$, $13.14 \mathrm{mmol})$ in pyridine $(2 \mathrm{~mL})$ was added 3 -methyl-2-butenal $(1.65 \mathrm{~mL}, 17.09 \mathrm{mmol})$ at ambient temperature. The reaction mixture was stirred for $2 \mathrm{~h}$ at $140^{\circ} \mathrm{C}$ under microwave irradiation and cooled to room temperature. The reaction mixture was diluted with EtOAc and $2 \mathrm{~N} \mathrm{HCl}$ solution. The organic layer was washed with water and brine, dried over $\mathrm{MgSO}_{4}$ and concentrated in vacuo. Purification of the residue via flash column chromatography on silica gel (EtOAc- $n-\mathrm{CH}_{2} \mathrm{Cl}_{2}-$ hexane $=1: 1: 20-1: 1: 15)$ afforded $2.03 \mathrm{~g}(71 \%)$ of the chromene 6 as pale yellow solid with a melting point of $101 \mathrm{ca} .103^{\circ} \mathrm{C}$ : FT-IR (thin film, neat) $v_{\max } 2976,1644,1624,1578,1487$, 1365, 1273, $1113 \mathrm{~cm}^{-1}$; ${ }^{1} \mathrm{H}-\mathrm{NMR}\left(400 \mathrm{MHz}, \mathrm{CDCl}_{3}\right) \delta: 12.94$ (s, $1 \mathrm{H}), 7.49$ (d, $1 \mathrm{H}, J=8.2 \mathrm{~Hz}), 6.69(\mathrm{~d}, 1 \mathrm{H}, J=10.0 \mathrm{~Hz}), 6.31$ (d, $1 \mathrm{H}, J=9.2 \mathrm{~Hz}), 5.56(\mathrm{~d}, 1 \mathrm{H}, J=10.0 \mathrm{~Hz}), 2.52(\mathrm{~s}, 3 \mathrm{H}), 1.43$ (s, 6H); low resolution (LR)-MS (FAB) $m / z 219\left(\mathrm{M}+\mathrm{H}^{+}\right)$; high resolution (HR)-MS (FAB) Calcd for $\mathrm{C}_{13} \mathrm{H}_{15} \mathrm{O}_{3}\left(\mathrm{M}+\mathrm{H}^{+}\right)$: 219.1016. Found 219.1029.

1-(5-Hydroxy-2,2-dimethylchroman-6-yl)ethanone

A suspension of chromene $6(1.00 \mathrm{~g}, 4.58 \mathrm{mmol})$ and $10 \% \mathrm{Pd} / \mathrm{C}$ $(50 \mathrm{mg})$ in EtOAc $(50 \mathrm{~mL})$ was stirred under $\mathrm{H}_{2}$ atmosphere at ambient temperature until no starting material was detected by TLC. The reaction mixture was filtered through a Celite pad and concentrated in vacuo. Purification of the residue via flash column chromatography on silica gel (EtOAc- $\mathrm{CH}_{2} \mathrm{Cl}_{2}-n$ hexane $=1: 1$ : 15) afforded $999 \mathrm{mg}(99 \%)$ of chromane 3 as a white solid with a melting point of $68-71^{\circ} \mathrm{C}$ : FT-IR (thin film, neat) $v_{\max } 2976,1627,1586,1370,1270,1118 \mathrm{~cm}^{-1}$; ${ }^{1} \mathrm{H}-\mathrm{NMR}$ $\left(400 \mathrm{MHz}, \mathrm{CDCl}_{3}\right) \delta: 13.08(\mathrm{~s}, 1 \mathrm{H}), 7.46(\mathrm{~d}, 1 \mathrm{H}, J=8.8 \mathrm{~Hz})$, $6.31(\mathrm{~d}, 1 \mathrm{H}, J=8.9 \mathrm{~Hz}), 2.67(\mathrm{t}, 2 \mathrm{H}, J=6.8 \mathrm{~Hz}), 2.52(\mathrm{~s}, 3 \mathrm{H})$, $1.79(\mathrm{t}, 2 \mathrm{H}, J=6.8 \mathrm{~Hz}), 1.33(\mathrm{~s}, 6 \mathrm{H}) ;{ }^{13} \mathrm{C}-\mathrm{NMR} \quad(75 \mathrm{MHz}$, $\left.\mathrm{CDCl}_{3}\right) \delta: 202.5,162.7,160.7,129.5,112.6,109.1,109.5,75.7$, 31.8, 26.7, 26.7, 26.0, 16.2; LR-MS (FAB) $\mathrm{m} / \mathrm{z} 221\left(\mathrm{M}+\mathrm{H}^{+}\right)$; HR-MS (FAB) Calcd for $\mathrm{C}_{13} \mathrm{H}_{17} \mathrm{O}_{3}\left(\mathrm{M}+\mathrm{H}^{+}\right)$: 221.1172. Found 221.1189 .

7,7-Dimethyl-8,9-dihydro-2 $\mathrm{H}$-furo[2,3- $f]$ chromen-3(7H)one (2) To a solution of 2'-hydroxyacetophenone $3(400 \mathrm{mg}$, $1.81 \mathrm{mmol})$ in tetrahydrofuran (THF) $(20 \mathrm{~mL})$ was dropwised $1 \mathrm{~m}$ lithium hexamethyldisilazide (LHMDS) solution in THF $(5.45 \mathrm{~mL}, 5.45 \mathrm{mmol})$ at $-78^{\circ} \mathrm{C}$. After $30 \mathrm{~min}$, trimethylsilyl chloride (TMSCl) $(0.92 \mathrm{~mL}, 7.26 \mathrm{mmol})$ was added and the resulting mixture was stirred for $4 \mathrm{~h}$ at same temperature. $\mathrm{N}$ Bromosuccinimide $(355 \mathrm{mg}, 1.99 \mathrm{mmol})$ in THF $(5 \mathrm{~mL})$ was dropwised for $10 \mathrm{~min}$ and the resulting mixture was stirred for $30 \mathrm{~min}$ at $-78^{\circ} \mathrm{C}$ and $30 \mathrm{~min}$ at ambient temperature. To the reaction mixture was added $1 \mathrm{~m}$ sodium hydroxide $(\mathrm{NaOH})$ solution $(10 \mathrm{~mL})$ at ambient temperature and stirred for $1 \mathrm{~h}$. The reaction mixture was diluted with EtOAc and water. The organic layer was washed with water and brine, dried over $\mathrm{MgSO}_{4}$ and concentrated in vacuo. Purification of the residue via flash column chromatography on silica gel (EtOAc- $n$-hexane- $\left.\mathrm{CH}_{2} \mathrm{Cl}_{2}=1: 1: 10\right)$ afforded $253 \mathrm{mg}(64 \%)$ 
of the benzofuranone $\mathbf{2}$ as pale yellow solid with a melting point of $148-150^{\circ} \mathrm{C}$, and trace amount of the bromoacetophenone 9: FT-IR (thin film, neat) $v_{\max }$ 2974, 1974, 1705, 1599, 1440, $1318 \mathrm{~cm}^{-1}$; ${ }^{1} \mathrm{H}-\mathrm{NMR}\left(400 \mathrm{MHz}, \mathrm{CDCl}_{3}\right) \delta: 7.35$ (d, $1 \mathrm{H}$, $J=8.8 \mathrm{~Hz}), 6.51(\mathrm{~d}, 1 \mathrm{H}, J=8.3 \mathrm{~Hz}), 4.69(\mathrm{~s}, 2 \mathrm{H}), 2.73(\mathrm{t}, 2 \mathrm{H}$, $J=6.8 \mathrm{~Hz}), 1.86(\mathrm{t}, 2 \mathrm{H}, J=6.8 \mathrm{~Hz}) ; 1.36(\mathrm{~s}, 6 \mathrm{H}) ;{ }^{13} \mathrm{C}-\mathrm{NMR}$ $\left(75 \mathrm{MHz}, \mathrm{CDCl}_{3}\right) \delta: 197.7,174.1,162.5,122.3,113.4,113.0$, 105.7, 76.2, 75.6, 31.4, 26.7, 26.7, 15.7; LR-MS (FAB) $\mathrm{m} / \mathrm{z}$ $219\left(\mathrm{M}+\mathrm{H}^{+}\right)$; HR-MS (FAB) Calcd for $\mathrm{C}_{13} \mathrm{H}_{15} \mathrm{O}_{3}\left(\mathrm{M}+\mathrm{H}^{+}\right)$: 219.1016. Found 219.1021.

1-[7(or 8)-Bromo-5-hydroxy-2,2-dimethylchroman-6-yl]ethanone (9) ${ }^{1} \mathrm{H}-\mathrm{NMR}\left(400 \mathrm{MHz}, \mathrm{CDCl}_{3}\right.$, mixture of regioisomers) $\delta$ : 7.76 and $7.58(1 \mathrm{H}, \mathrm{s}), 2.73-2.66(\mathrm{~m}, 2 \mathrm{H}), 2.56-2.54$ (m, 3H), 1.85-1.81 (m, 2H), 1.36-1.34 (m, 6H); LR-MS (FAB) $m / z 299\left(\mathrm{M}+\mathrm{H}^{+}\right)$.

(Z)-2-(4-Hyd roxybenzylidene)-7,7-dimethyl-8,9-dihydro-2 $H$-furo[2,3- $f$ ] chromen-3(7H)-one (Damaurone D, 1) To a solution of benzofuranone $2(100 \mathrm{mg}, 0.46 \mathrm{mmol})$ and 4-hydroxybenzaldehyde $(56 \mathrm{mg}, 0.46 \mathrm{mmol})$ in anhydrous EtOH $(10 \mathrm{~mL})$ was added piperazine $(4.3 \mathrm{mg}, 0.05 \mathrm{mmol})$. The reaction mixture was refluxed for $24 \mathrm{~h}$ and then diluted with EtOAc and saturated $\mathrm{NH}_{4} \mathrm{Cl}$ aqueous solution. The organic layer was washed with water and brine, dried over $\mathrm{MgSO}_{4}$ and concentrated in vacuo. Purification of the residue via flash column chromatography on silica gel $(\mathrm{MeOH}-$ $\left.\mathrm{CH}_{2} \mathrm{Cl}_{2}=1: 100-1: 50\right)$ afforded $139 \mathrm{mg}(94 \%)$ of the damaurone D (1) as yellow solid with a melting point of $276-279^{\circ} \mathrm{C}$; FT-IR (thin film, neat) $v_{\max } 1680,1595,1513,1437,1281,1130$, $1059 \mathrm{~cm}^{-1}$; ${ }^{1} \mathrm{H}-\mathrm{NMR}\left(500 \mathrm{MHz}\right.$, pyridine- $\left.d_{5}\right) \delta: 12.46$ (brs, $1 \mathrm{H}), 8.07(\mathrm{~d}, 2 \mathrm{H}, J=8.6 \mathrm{~Hz}), 7.66(\mathrm{~d}, 1 \mathrm{H}, J=8.5 \mathrm{~Hz}), 7.33(\mathrm{~d}$, $2 \mathrm{H}, J=8.6 \mathrm{~Hz}), 7.17(\mathrm{~s}, 1 \mathrm{H}), 6.73(1 \mathrm{H}, \mathrm{d}, J=8.4 \mathrm{~Hz}), 2.67(\mathrm{t}$, $2 \mathrm{H}, J=6.7 \mathrm{~Hz}), 1.70(\mathrm{t}, 2 \mathrm{H}, J=6.7 \mathrm{~Hz}), 1.27(\mathrm{~s}, 6 \mathrm{H}) ;{ }^{1} \mathrm{H}-\mathrm{NMR}$ $\left(400 \mathrm{MHz}, \mathrm{CD}_{3} \mathrm{OD}\right) \delta: 7.81(\mathrm{~d}, 2 \mathrm{H}, J=8.8 \mathrm{~Hz}), 7.48(\mathrm{~d}, 1 \mathrm{H}$, $J=8.8 \mathrm{~Hz}), 6.88(\mathrm{~d}, 2 \mathrm{H}, J=8.8 \mathrm{~Hz}) ; 6.78(\mathrm{~s}, 1 \mathrm{H}), 6.62(\mathrm{~d}, 1 \mathrm{H}$, $J=8.0 \mathrm{~Hz}), 2.94$ (t, 2H, $J=6.8 \mathrm{~Hz}), 1.95$ (t, 2H, $J=6.8 \mathrm{~Hz}), 1.41$ $(\mathrm{s}, 6 \mathrm{H}) ;{ }^{13} \mathrm{C}-\mathrm{NMR}\left(100 \mathrm{MHz}\right.$, pyridine- $\left.d_{5}\right) \delta$ : 182.7, 165.9, $161.8,161.0,147.1,134.1,134.1,124.4,123.0,117.1,117.1$, 114.3, 114.2, 112.3, 106.2, 76.6, 31.3, 26.6, 26.6, 16.0; LR-MS (FAB) $m / z 323\left(\mathrm{M}+\mathrm{H}^{+}\right)$; HR-MS (FAB) Calcd for $\mathrm{C}_{20} \mathrm{H}_{19} \mathrm{O}_{4}$ $\left(\mathrm{M}+\mathrm{H}^{+}\right):$323.1278. Found 323.1283.

3-(4,5-Dimethylthiazol-2-yl)-2,5-diphenyltetrazolium Bromide (MTT) Assay Cell viability was determined by MTT assay. Raw264.7 Macrophages were incubated with the damaurone D (1) at different concentrations for 24h in 96-well culture plates. After incubation, MTT $(0.5 \mathrm{mg} / \mathrm{mL}$ in phosphate buffered saline (PBS)) $20 \mu \mathrm{L}$ was added to each well and the cells were further incubated for $4 \mathrm{~h}$ at $37^{\circ} \mathrm{C}$. The formation of violet precipitate formazan was monitored at a wavelength of $560 \mathrm{~nm}$ and $670 \mathrm{~nm}$ with spectrophotometer.

Treatment of Compounds Raw264.7 Macrophages were pretreatment with damaurone D (1) or butein at different concentrations for $1 \mathrm{~h}$ and then treatment with LPS $10 \mathrm{ng} / \mathrm{mL}$ for $24 \mathrm{~h}$ in 12 -well cell culture plate.

Western Blot Cells were harvest with lysis buffer containing $10 \mathrm{~mm}$ Tris- $\mathrm{HCl}(\mathrm{pH} 7.1), 100 \mathrm{~mm} \mathrm{NaCl}, 1 \mathrm{~mm}$ ethylenediaminetetraacetic acid (EDTA), 10\% glycerol, $0.5 \%$ Triton X-100, 0.5\% Nonidet P-40, $1 \mathrm{~mm}$ dithiothreitol and $0.5 \mathrm{~mm}$ phenylmethylsulfonyl fluoride, supplemented with inhibitors of proteinase and phosphatase. The protein concentrations in the cell lysates were determined by using a Bio-Rad Protein Assay (Bio-Rad Laboratories, Hercules, CA,
U.S.A.). The aliquots of lysates were eletrophoresed in 6-10\% sodium dodecyl sulfate-polyacrylamide gels $(20 \mu \mathrm{g}$ of protein/ lane). The separated proteins were transferred to nitrocellulose membranes (GE Healthcare). The membranes were blocked with $0.4 \%$ skim milk in Tris-buffered saline containing $1 \%$ Tween 20 and incubated with the primary antibodies, followed by incubation with secondary antibodies. Immunoreactive protein was visualized by ECL chemiluminescence detection kit (Amersham Biosciences, Buckinghamshire, U.K.). Image was obtained using ChemiDoc ${ }^{\mathrm{TM}} \mathrm{XRS}+$ System (Bio-Rad) or conventional developing method using Kodak film. Primary antibodies used were: iNOS from BD Biosciences (Palo Alto, CA, U.S.A.), $\beta$-tubulin (\#PA1-16947) from Thermo Scientific (Waltham, MA, U.S.A.), and COX-2 (sc-1745) from Santa Cruz Biotechnology (Santa Cruz, CA, U.S.A.).

Measurement of Nitric Oxide (NO) Levels Production of NO was estimated by measuring the amount of nitrite (a stable metabolite of NO) using the Griess reagent. Briefly, cells were pretreated with DD for $1 \mathrm{~h}$ before the addition of LPS. After $24 \mathrm{~h}$, aliquots of culture supernatants were mixed with an equal volume of a modified Griess reagent comprising a $1: 1$ mixture of $1 \%$ sulfanilamide in $30 \%$ acetic acid and $0.1 \%$ $N$-(1-naphthyl)ethylenediamine dihydrochloride in $60 \%$ acetic acid, at room temperature for $5 \mathrm{~min}$, and absorbance was measured at $540 \mathrm{~nm}$ using a spectrophotometer.

Statistical Analyses Data are provided as mean \pm standard error of the mean (S.E.M.) values. The significance of differences between treatment groups was determined by one-way ANOVA with the Turkey's post-hoc test using GraphPad Prism v4.0 (GraphPad, San Diego, CA, U.S.A.). $p<0.01$ was considered significant.

Acknowledgment The present research was conducted by the research fund of Dankook University in 2015.

Conflict of Interest The authors declare no conflict of interest.

\section{References}

1) Ono E., Fukuchi-Mizutani M., Nakamura N., Fukui Y., YonekuraSakakibara K., Yamaguchi M., Nakayama T., Tanaka T., Kusumi T., Tanaka Y., Proc. Natl. Acad. Sci. U.S.A., 103, 11075-11080 (2006).

2) Boumendjel A., Curr. Med. Chem., 10, 2621-2630 (2003).

3) Zwergel C., Gaascht F., Valente S., Diederich M., Bagrel D., Kirsch G., Nat. Prod. Commun., 7, 389-394 (2012).

4) Haudecouer R., Ahmed-Belkacem A., Yi W., Fortuné A., Brillet R., Belle C., Nicolle D., Pallier C., Pawlotsky J.-M., Noumendjel A., J. Med. Chem., 54, 5395-5402 (2011).

5) Meguellati A., Ahmed-Belkacem A., Yi W., Haudecoeur R., Crouillère M., Brillet R., Pawlotsky J. M., Boumendjel A., Peuchmaur M., Eur. J. Med. Chem., 80, 579-592 (2014).

6) Li Y.-K., Sun J.-Q., Gao X.-M., Lei C., Helv. Chim. Acta, 97, 414419 (2014).

7) Basim E., Basim H., Fitoterapia, 74, 394-396 (2003).

8) Kwon E.-K., Lee D.-Y., Lee H., Kim D.-O., Baek N.-I., Kim Y.-E., Kim H.-Y., J. Agric. Food Chem., 58, 882-886 (2010).

9) Mahmood N., Piacente S., Pizza C., Burke A., Khan A. I., Hay A. J., Biochem. Biophys. Res. Commun., 229, 73-79 (1996).

10) Gholamhoseinian A., Fallah H., Sharififar F., Phytomedicine, 16, 935-941 (2009).

11) Nicolaou K., Pfefferkorn J., Roecker A., Cao G.-Q., Barluenga S., Mitchell H., J. Am. Chem. Soc., 122, 9939-9953 (2000).

12) Carrasco M. P., Newton A. S., Goncalves L., Gois A., Machado M., 
Gut J., Nogueira F., Hanscheid T., Guedes R. C., dos Santos D. J. V. A., Rosenthal P., Moreira R., Eur. J. Med. Chem., 80, 523-534 (2014).

13) Shin S. Y., Shin M. C., Shin J.-S., Lee K.-T., Lee Y. S., Bioorg. Med. Chem. Lett., 21, 4520-4523 (2011).

14) Haudecoeur R., Boumendjel A., Curr. Med. Chem., 19, 2861-2875 (2012).

15) Lee S. H., Seo G. S., Sohn D. H., Biochem. Biophys. Res. Commun., 323, 125-132 (2004).

16) Lee Y. R., Hwang J. K., Koh H. W., Jang K. Y., Lee J. H., Park J. W., Park B. H., Life Sci., 90, 799-807 (2012).

17) Song M. Y., Jeong G. S., Lee H. S., Kwon K. S., Lee S. M., Park J. W., Kim Y. C., Park B. H., Biochem. Biophys. Res. Commun., 400, 83-88 (2010)

18) Bandaranayake W. M., Crombie L., Whiting D. A., J. Chem. Soc. C, 1971, 804-914 (1971).
19) Gupta S., Shivahare R., Korthikunta V., Singh R., Gupta S., Tadigoppula N., Eur. J. Med. Chem., 81, 359-366 (2014).

20) Narender T., Reddy K. P., Shweta, Synth. Commun., 39, 384-394 (2009).

21) Mutai T., Sawatani H., Shida T., Shono H., Araki K., J. Org. Chem., 78, 2482-2489 (2013).

22) Martín Rodriquez E., Bogdan N., Capobianco J. A., Orlandi S., Cavazzini M., Scalera C., Quici S., Dalton Trans., 42, 9453-9461 (2013).

23) Skoumbourdis A. P., Huang R., Southall N., Leister W., Guo V., Cho M.-H., Inglese J., Nirenberg M., Austin C. P., Xia M., Thomas C. J., Bioorg. Med. Chem. Lett., 18, 1297-1303 (2008).

24) Andersen N. G., Parvez M., McDonald R., Keay B. A., Can. J. Chem., 82, 145-161 (2004)

25) Won T. H., Song I.-H., Kim K.-H., Yang W.-Y., Lee S. K., Oh D.-C., Oh W.-K., Oh K.-B., Shin J., J. Nat. Prod., 78, 666-673 (2015). 